\title{
EFL Teachers' Prosocial Behaviors at the Secondary Level in Bangladesh
}

\author{
Mohammad Ehsanul Islam Khan \\ Department of English, Manarat International University, Dhaka, Bangladesh \\ Received May 11, 2020 ; Revised June 27, 2020; Accepted July 20, 2020
}

Copyright $\mathrm{C} 2020$ by authors, all rights reserved. Authors agree that this article remains permanently open access under the terms of the Creative Commons Attribution License 4.0 International License

\begin{abstract}
The present comprehensive study dealt with the psychosocial perspectives of English as Foreign Language (EFL) teachers' academic activities or behaviors at the secondary level education in Bangladesh. Students are usually undernourished and very weak in English in the Bangladeshi EFL context, and no methods seem to improve the situation deploying any tactic or technique. The approaches have also been proved to be inappropriate in the last two decades for the teaching of the English language in Bangladesh. So, the study intends to find out the reasons behind the failure and the possible ways to develop English skills among the Bangladeshi EFL students by analyzing their teachers' academic and prosocial behaviors both inside and outside the classroom. The researcher collected data from 47 English teachers and 96 students of 16 secondary and higher secondary level institutions. The most supportive tools for this study were questionnaire survey and teacher interviews with phenomenological analyses of the participants' replies. The data were analyzed with conceptual and relational inquisition of the academic prosocial behaviors and features of the English language teachers in both the qualitative and quantitative approaches. The upshot of the study is, in fact, a report of the understandings and needs of the current condition of teaching and prosocial behaviors of the secondary level English teachers outside the classroom. The result displayed the lacking of relationships between teachers and students along with the needs of developing teachers' prosocial behaviors through kaizen, resilience, effective teacher-training, and teacher-research with the contemplation of non-verbal cues.
\end{abstract}

Keywords Prosocial Behavior, Resilience, Nonverbal Signals, Training, Teacher-Research

\section{Introduction}

Teachers are the essence of a teaching-learning environment. Their behavior, approach, attitude, talking style, posture, gesture, and even fashion are considered as the central facets in an educational institution because "the behavior and approach of the teacher are directly accepted and copied by students, which puts great responsibilities on the teachers" [34]. Teachers must think, rethink, study, analyze, and envisage the lessons they intend to teach in their everyday classes in professional places. Every good teacher must have good preparation in all moments especially before entering into a class. A teacher should also be adequately interactive and friendly to the students during the counseling hours. Such characteristics are also examples of their prosocial behaviors. In connection to that, Blazar \& Kraft's [5] emotional support includes teacher behaviors such as their understanding to students, consideration for students' viewpoints, and the degree to which they generate a constructive environment in the classroom.

The advanced constructive behavior of teachers towards the students led to the elevated scholarly attainment of the students [28]. Moreover, Ulug, Ozden, and Eryilmaz [34] also believe that the outcome of the teacher in the individuality growth and achievement of students is a fact that can't be ignored anyway. However, such behavior is rarely found among the EFL teachers, especially at the secondary level in Bangladesh. In many of the cases, the EFL students are found with inadequate efficiency of basic four skills and are yet to develop their skills even after passing their twelve years of study of secondary and higher secondary level education. English, the worldwide language is still to be imperatively introduced to the students of many areas of the country. Consequently, 'English' has become merely a subject to get marks in the exams than that of trying to learn and master it. 


\section{Objectives}

The primary objective of this study is to reveal the truth of active/inactive and academic/non-academic behaviors of the English teachers at the secondary level in Bangladesh. As the overall education system is yet to be developed more in Bangladesh, the study looks into the root problems among the secondary level EFL teachers of the country.

\section{Literature Review}

EFL teachers' capabilities vary from person to person, institution to institution, and region to region in Bangladesh $[1,25]$. On the other hand, many teachers come to the teaching profession after being rejected by other expected jobs. Alam [1] also added that the improvement of teaching behaviors does not usually receive any increase after joining the teaching profession. In a meta-analysis, Südkamp, Kaiser and Möller [33] tinted the significance that a teacher's predisposed judgment or expectations hold for the actual academic well-being of the students. However, teachers' prosocial behavior inside and outside the class is sometimes inappropriate. In a developing country like Bangladesh, the teacher selection process is not always effective. Stating such a concept, Peters [22] emphasizes the significance of the teaching and learning context and the student-teacher rapport in the school scenery, noting the importance of being vigilant to the miscellany of the students' backgrounds and experiences. So, the real teachers are very often ignored in the teaching profession though the ability of teachers to organize classrooms and manage the behavior of their students is critical to achieving the positive educational outcomes [20]. Besides, classroom management facilitates both learners and educators; and if classrooms are not aptly managed, students may show hazardous performance and can create a hazard to the school's benign situation [24]. Consequently, the students are not grown up with proper learning as all the teachers are not being able to discharge their learning credibly and fruitfully.

Teachers must seek for the ways to enhance his/her insights about meticulous students' needs for learning and so become approachable according to those needs. This should be repeatedly done in collaboration with colleagues. In another side, they must behave prosocially with the students for the proper output regarding Batson's [4] clarification that 'prosocial behavior' denotes an extensive variety of actions deliberate to facilitate one or more public other than oneself- activities such as "helping, comforting, sharing and cooperation".

In other studies, like $[6,17]$ it is suggested that expert teachers are considerate and solicitous for they do not only worry about hoist students' exam scores but also to give psychologically supportive atmospheres that can enhance the students' shared and cognitive expansion. They also think about the successful pro-social behaviors in the classroom, provide exact content to the students, and maintain decisive thinking [23].

Hallinan [12] thinks that if academic success is to be maximized, both the cognitive and socio-psychological dimensions should be considered. Regrettably in Bangladesh, most of our teachers are found to be inactive before or after the classes. So, they can't deliver their lectures with the best understanding of their knowledge; and very often it so happens that the teachers are hindered by their incomplete learning and less or no preparation [26]. In consequence, the students are not also vividly getting their learning outcomes. So, the overall EFL learning process falls in vain.

\section{Methodology}

The present study was conducted during the period of January-2019 to July-2019. The researcher collected data in a mixed-method with both qualitative and quantitative approaches. The researcher administered a questionnaire survey among the teacher-participants and the student-participants with a five-point Likert scale having five different agreements e.g. strongly agree (SA), agree (A), neutral (N), disagree (D) and strongly disagree (SD).

Forty-seven (47) EFL teachers and ninety-six (96) students from sixteen (16) secondary and higher secondary level institutions including schools and colleges in Dhaka (7), Tangail (2), Cumilla (2) and Kishoregonj (5) districts of Bangladesh were the key participants of the study. The districts were also selected pre-considering the easiest commuting from the researcher's place to facilitate the research work. The sampling of data covered two different divisions that are Dhaka and Chattogram to collect the target information from a broad-spectrum perspective. The demographic profiles of the 47 teacher-participants are shown in Table 1:

Table 1. Teachers' demographic profile

\begin{tabular}{|c|c|c|c|c|c|}
\hline Teaching Experiences & Total & Education & Total & Level of Teaching & Total \\
\hline 0-2 years & 17 & BA (Pass) & 04 & Junior Secondary & 03 \\
\hline 3-5 years & 11 & BA (Honors) & 10 & Secondary & 29 \\
\hline 6-10 years & 14 & BA (Honors), MA & 31 & \multirow{2}{*}{$\begin{array}{c}\text { Higher Secondary } \\
\text { (Intermediate) }\end{array}$} & 15 \\
\hline Above 10 years & 05 & M. Phil./PhD & 02 & . \\
\hline
\end{tabular}


Above table 1 shows the demographic profile of the teacher-participants of the study whose behavior was the subject matter of information. BA (pass) degree mentioned in table-1 is a 'Bachelor of Arts' degree in Bangladesh which is not equivalent to honors. It is commonly known as the 'pass course' and a supportive degree to be a teacher at the junior secondary or secondary level in Bangladesh though to teach at the higher secondary level, a BA (pass) degree holder must possess 'First Class' result in Master's degree.

The questionnaire survey provides the answers to the first research question looking into the teachers' pro-social behaviors especially before and after the classroom activities which was the major concern of the research because the study hypothesized that most of the teachers might not get any touch with academic activities or teacher-student relationships to develop themselves to discharge their learning in the classrooms.

However, interviews with the teachers were also conducted for collecting relevant data about the behavioral aspects. The interview sections depicted the foremost reasons for the teachers' unwanted academic behaviors, classroom preparation, and possible ways out of those quandaries which were noted vigilantly by the researcher. The interview replies were analyzed through a keen phenomenological account from where the researcher collected the answers to the third research question. The interview was analyzed as a phenomenological study.

\section{Results and Discussion}

The result section has depicted the fact of the teachers' prosocial behavior. The questionnaire survey brought out the quantitative data to know about the teachers' behavior. The questionnaire was also imperative to match the collected responses of the teacher-participants and student-participants. Then the mean of their answers was considered to know the exact response. Thus, the fact was brought to light how the teachers behave prosocially and to what extent the teachers and the students express it. All the information afterward was intermingled to get the final result of the study.

\subsection{Analyses of Questionnaire Survey and Interviews}

A language teacher must be sociable and approachable. The present study reflected on those points to find out how far the teachers are perfect to be a language teacher. For that reason, the researcher sought aspects of EFL teachers' prosocial behaviors to evaluate their language teaching ability in the Bangladeshi context. The questionnaire survey found a significant difference between the responses of teacher participants and student participants in most of the statements. However, the differences in the mean values demonstrated that the students are not satisfied or the EFL teachers might not practice a set of standard principles for behaving and interacting prosocially. For the sample statements, the mean values differed at least from $0.04 \geq$ to $\leq 1.53$ in the responses. Overall, the scenario was frustrating for a developing country like Bangladesh that struggles to make a highly educated nation.

The researcher found that the students opined their views very frankly about what they are getting from their teachers regarding behavior socially and personally. And the value proves that they are not in the similar opinions with their teachers in most of the regards. Therefore, the researcher believes that the responses where at least 0.25 is a difference between the mean of the responses of TP and SP should indeed be the concern for the respective authority. In the cases, where the difference is less than 0.25 may be resolved by regular training and workshops. The mean values varied regarding teachers' friendliness and support outside the classroom, use of interesting study materials, use of slang words, timing in the classroom, teachers' frankness, feedback, cooperation, biased judgment, and smoking before the students. In such cases, the study emphasized that the teachers should be trained, nurtured, and taken into consideration seriously to avoid the students' dissatisfaction. Training programs are continually arranged by the government of Bangladesh. However, not always these training programs can have a fruitful impact upon the education system that was later also reflected from the teacher interviews because many teachers receive training but cannot deploy their learning for the betterment of the students.

However, the interview segment was analyzed phenomenologically. The participants exposed their answers in two sentences utmost including personal opinions. In phenomenological studies, sampling is considered as "choosing informants" [6] which means what is appraised is the people [11]. Therefore, being the sample participants, the teachers played the role of informants in this segment and their opinions were the representative data for the study.

\subsection{Questionnaire Survey: Presentation and Interpretation of Data}

A similar questionnaire was administered to both the teacher-participants (TP) and the student-participants (SP) to collect their responses. Later, the results were crisscrossed to find out the facts about the teachers' prosocial behaviors. 
Table 2. Responses of TP and SP regarding teachers' prosocial behavior

\begin{tabular}{|c|c|c|c|c|c|c|c|c|}
\hline SL & Statements & Response & SA (5) & A (4) & $\mathrm{N}(3)$ & $\mathrm{D}(2)$ & SD (1) & Mean \\
\hline \multirow{2}{*}{1} & \multirow{2}{*}{$\begin{array}{l}\text { Teachers are very friendly and smiley to the } \\
\text { students outside the classroom. }\end{array}$} & TP & 17 & 19 & 4 & 7 & 0 & 3.98 \\
\hline & & $\mathrm{SP}$ & 16 & 27 & 42 & 7 & 2 & 3.44 \\
\hline \multirow{2}{*}{2} & \multirow{2}{*}{$\begin{array}{l}\text { Teachers are supportive outside the class to } \\
\text { help the students if they are not tacit in the } \\
\text { classroom. }\end{array}$} & TP & 11 & 32 & 0 & 3 & 1 & 4.04 \\
\hline & & SP & 8 & 22 & 19 & 9 & 38 & 2.51 \\
\hline \multirow{2}{*}{3} & \multirow{2}{*}{$\begin{array}{l}\text { Teachers are well-prepared about the day's } \\
\text { lesson in every class. }\end{array}$} & TP & 8 & 9 & 16 & 9 & 5 & 3.13 \\
\hline & & $\mathrm{SP}$ & 19 & 13 & 33 & 11 & 19 & 2.99 \\
\hline \multirow{2}{*}{4} & \multirow{2}{*}{$\begin{array}{l}\text { Teachers often use audio-visual aids for the } \\
\text { enhancement of the students' knowledge and } \\
\text { learning process. }\end{array}$} & $\mathrm{TP}$ & 13 & 21 & 6 & 4 & 3 & 3.79 \\
\hline & & SP & 5 & 37 & 2 & 33 & 19 & 2.75 \\
\hline \multirow{2}{*}{5} & \multirow{2}{*}{$\begin{array}{l}\text { Teachers sometimes use informal/ slang } \\
\text { words inside the classroom. }\end{array}$} & TP & 0 & 0 & 11 & 31 & 5 & 2.13 \\
\hline & & SP & 0 & 14 & 33 & 41 & 8 & 2.55 \\
\hline \multirow{2}{*}{6} & \multirow{2}{*}{$\begin{array}{l}\text { Teachers share their positive and negative life } \\
\text { experiences with the students for their better } \\
\text { considerate of lifestyle. }\end{array}$} & $\mathrm{TP}$ & 17 & 24 & 6 & 0 & 0 & 4.23 \\
\hline & & SP & 36 & 42 & 13 & 5 & 0 & 4.13 \\
\hline \multirow{2}{*}{7} & \multirow{2}{*}{$\begin{array}{l}\text { Teachers are always on or in time in the } \\
\text { classroom. }\end{array}$} & $\mathrm{TP}$ & 5 & 28 & 11 & 3 & 0 & 3.74 \\
\hline & & $\mathrm{SP}$ & 7 & 35 & 10 & 26 & 18 & 2.86 \\
\hline \multirow{2}{*}{8} & \multirow{2}{*}{$\begin{array}{l}\text { Teachers frankly and willingly donate for } \\
\text { charitable works done by the students e.g. } \\
\text { relief fund, warm clothes for the poor, etc. }\end{array}$} & $\mathrm{TP}$ & 11 & 15 & 13 & 8 & 0 & 3.61 \\
\hline & & SP & 19 & 17 & 24 & 27 & 9 & 3.10 \\
\hline \multirow{2}{*}{9} & \multirow{2}{*}{$\begin{array}{l}\text { Teachers provide counseling hours to the } \\
\text { students to discuss their academic and } \\
\text { personal quandaries if any. }\end{array}$} & $\mathrm{TP}$ & 2 & 16 & 7 & 20 & 2 & 2.91 \\
\hline & & $\mathrm{SP}$ & 0 & 29 & 38 & 23 & 6 & 2.94 \\
\hline \multirow{2}{*}{10} & \multirow{2}{*}{$\begin{array}{l}\text { Teachers ignore the students' queries and do } \\
\text { not provide feedback timely. }\end{array}$} & $\mathrm{TP}$ & 0 & 4 & 5 & 26 & 12 & 2.02 \\
\hline & & SP & 11 & 25 & 31 & 21 & 8 & 3.10 \\
\hline \multirow{2}{*}{11} & \multirow{2}{*}{$\begin{array}{l}\text { Teachers are often biased while marking the } \\
\text { exam scripts and sometimes mock at students' } \\
\text { failure. }\end{array}$} & $\mathrm{TP}$ & 5 & 16 & 10 & 14 & 2 & 3.17 \\
\hline & & SP & 19 & 48 & 20 & 9 & 0 & 3.80 \\
\hline \multirow{2}{*}{12} & \multirow{2}{*}{$\begin{array}{l}\text { Teachers cooperate and inspire the students in } \\
\text { doing innovative and intellectual projects. }\end{array}$} & TP & 13 & 29 & 4 & 1 & 0 & 4.15 \\
\hline & & SP & 26 & 30 & 33 & 4 & 0 & 3.72 \\
\hline \multirow{2}{*}{13} & \multirow{2}{*}{$\begin{array}{l}\text { Teachers are well trained and successful in } \\
\text { conducting EFL classes in English. }\end{array}$} & TP & 0 & 13 & 5 & 15 & 14 & 2.36 \\
\hline & & SP & 0 & 21 & 6 & 52 & 17 & 2.32 \\
\hline \multirow{2}{*}{14} & \multirow{2}{*}{$\begin{array}{l}\text { Teachers use different teaching tactics and } \\
\text { materials in the EFL classroom for making the } \\
\text { lesson more intelligible. }\end{array}$} & $\mathrm{TP}$ & 13 & 19 & 0 & 15 & 0 & 3.64 \\
\hline & & SP & 16 & 43 & 13 & 20 & 4 & 3.49 \\
\hline \multirow{2}{*}{15} & nes, teachers smoke be & TP & 4 & 7 & 5 & 14 & 17 & 2.29 \\
\hline & with other colleagues. & SP & 12 & 32 & 11 & 23 & 18 & 2.97 \\
\hline
\end{tabular}

Table- 2 above shows the opinions and thoughts of both the students and the teachers regarding teachers' prosocial behavior. In statement-1, the teachers and the students have opined in a bit different manner. Teachers consider themselves as friendly and frank outside the classroom whereas students do not consider the same at a satisfactory level. In statement-2, most of the students opined that the teachers are not supportive outside the class though the teachers quite claimed to be supportive. It so happens in such an EFL context for the defective interactional system between teachers and students in the institutions. Lack of teacher training is also a factor in this regard. In the statement-3, teachers and students expressed a fairly similar view that the teachers are not well prepared in the classroom. Both the participants opined in neutral. In statement-4, again dissimilar views become focused on using audiovisual aids to enhance the students learning process. Teachers opined that they are using audio-visual aids which is one of the key features of the Government of Bangladesh's mission of "Digital Bangladesh" but the students disagreed this point. In this regard, the teachers behaved the opposite of Allan [2] views that the "video is a good means of bringing a slice of living language into the classroom". Allan [2] also mentioned that video clips can provide "an important visual stimulus for language production and practice" (p.1).

Next, the teachers did not agree that they use informal or slang words in the classroom but few students opined in affirmative in statement -5 . Then, both the teachers and students agreed in the same viewpoint in statement- 6 that 
the teachers share their life experiences in the classroom which is indeed significant for the psychological growth of the students what views similar like Rashid and SaeedUzZaman [27] that the learning arc is amplified when a student thinks more like a teacher, and the teacher, a student; though later in statement-7 the participants hold opposing views about teachers' timing in the classroom. The students are found neutral about teachers' charitable deeds whereas teachers are also neutral in this statement-8. It proves that teachers' altruistic works are at an average level of satisfaction. It may happen because the teachers' salary in Bangladesh is very poor and most often teaching is an ignored area of professional fields. So, teachers are not concentrating on the extent the students expect from them. In statement-9, a crucial truth is depicted. In Bangladesh, there are hardly any secondary or higher secondary institutions where the teachers provide counseling hours to the students. Most of the participants agreed that there is no counseling hour for the students after class time.

In statement-10, teachers completely disagree that they ignore students' queries and do not provide feedback timely, though the student participants were found neutral. The replies of the statement-10 opposed the idea of Rashid \& SaeedUzZaman [27] that the cooperative behavioral patterns adopted by teachers positively impact students' motivational level, and consequently, their overall performance. Unfortunately, our students are not getting that motivation. In statement-11, teachers' partiality or biased marking and mocking the students' failure was judged where teachers found closer to the neutral in the Mean point (3.17) but the students agreed with the view (3.80). Gecer [10] believes that such behavior of teachers has a great negative effect upon the students.

Teachers $(\mathrm{Mean}=4.15)$ believe in statement-12 that they cooperate and inspire students in intellectual projects while students' Mean is 3.72 that is closer to their affirmative concept. Both the participants agreed in statement-13 that the teachers are not well trained to take EFL classes in English. In statement-14, the Means were critical to discuss Students' opinions are in between neutral and agree. Teachers opined that they use different teaching tactics and materials in the classroom.

In an overview, it can be considered that teachers use different tactics and teaching aids to make the lessons more legible. Rashid and SaeedUzZaman [27] also opined similarly that teaching behavior is enacted upon its base material- its content, which comes in the form of the instructions provided by the teachers in class. Finally, in statement-15, the teachers disagreed about their smoking in front of the students but the students' Mean (2.97) makes their opinion neutral.

\subsection{Teachers' Interviews}

The teacher-participants were asked five questions in a semi-structured interview session to get the related information about their pro-social behavior as the "semi-structured interviews are more about flexibility and generation of more useful data" [21]. Their replies to those questions are summed up below.

\subsubsection{Question-01: Do you share conflicts and debates} about study topics with your colleagues whenever required?

The first question received diversified answers. 57.45\% of the participants (27) answered that they discuss problems with the colleagues but others $(42.55 \%)$ disagreed. Figure-1 shows that the discussion among the teachers is not appreciable which impedes developing prosocial behaviors among themselves.

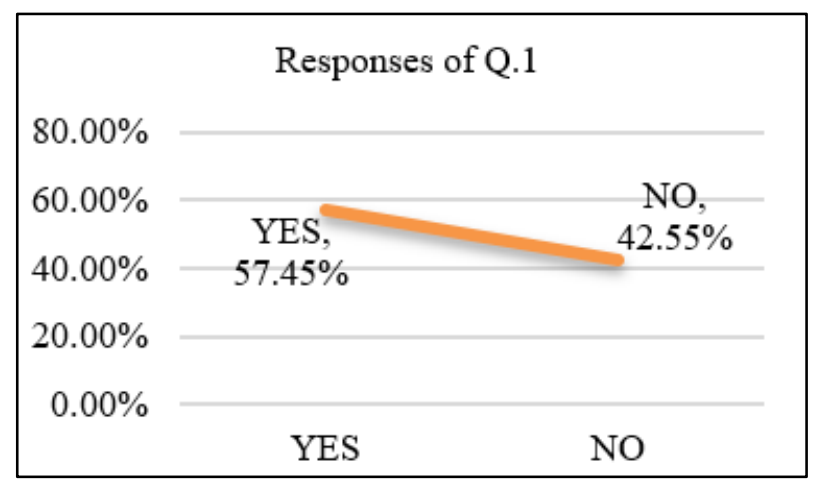

Figure 1. Opinions on sharing conflictions and debates about study topics with the colleagues

\subsubsection{Question-02: How many times have you received training on your subjective knowledge or ICT?}

32 of the teacher-participants $(68.08 \%)$ received training on the subjective knowledge and ICT while others did not receive any such training. Nevertheless, 22 participants (46.81\%) opined that the training programs are not always effective and deployed in the classroom because of its inefficacy and lack of technological supports. So, the teachings are not facilitated in the language classroom and the training remains inside the certificates. Even some participants strongly opined that few teachers received training on ICT but can conduct multimedia classes. It is because, most of the time, the trainings end without any evaluation of the trainees.

\subsubsection{Question-03: Are you involved in writing literary, social, educational, or linguistic issues in newspapers, magazines, or journals?}

In response to question-03, the researcher found that only 11 participants $(23.40 \%)$ are found active with creative and research related writings in the public domain which is regretful while $76.60 \%$ are deskbound in such creative works. Figure. 2 depicts the passiveness of the participants in creative writings for which, it is logical that they also do not encourage students in such creative works that opposes the idea of prosocial attitude. 


\section{Responses for Q.3}

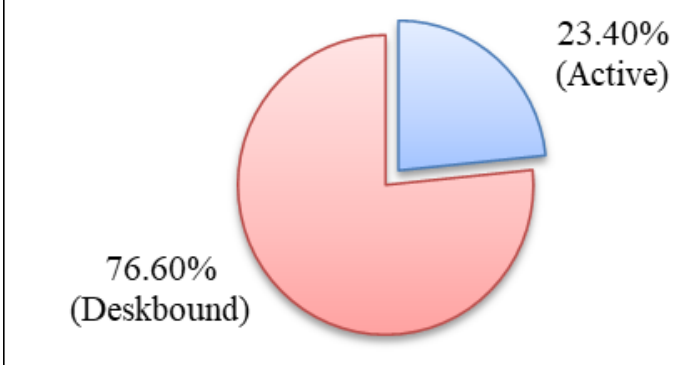

Figure 2. The extent of involvement in creative works

\subsubsection{Question-04: Do you study regularly before entering} into an EFL classroom?

This question received affirmative answers from 34 of the participants which are $72.34 \%$, though others admitted that they can't always study before entering into an EFL classroom. The responses also did not find a match with the responses of statement-3 of the questionnaire in 5.2.

\subsubsection{Question-05: Do you think you are 'always' prepared to encounter the students' problems and sharing personal or familial issues?}

Teacher's behavior with a feeling of hope, generosity, respect, and joy becomes effective in modifying and improving the conduct by the felonious students who have had previous bad records [35]. However, all the participants answered alike that they are not always prepared to share the personal and familiar issues of the students except in any serious case. Many of them opined that it depends upon different social issues and facts. Few teachers showed their interest but they were not agreed with the word 'always'. In consequence, students are not getting the proper treatment from their teachers.

\section{Recommendations}

Joyce [15] says that behavior is a kind of visible, individual fact. Teacher's behavior in the attitudinal sense is a substantial factor and it has a prodigious effect on student's character and success [29]. Here, the study aimed at finding out the effects of teachers' prosocial behavior and provided solutions with some key physiognomies to be the ideal teachers. So, the following imperative aspects may be useful for teachers' professional development to develop prosocial behavior.

\subsection{Ensuring Professional Development}

After analyzing the data, the study strongly suggested the teachers have kaizen, a Japanese term for continuous development in their behavior to be updated with the current affairs of the country as well as the world. The term was first disseminated by Imai [14] through his book which is an approach based on cooperation and commitment stating that small but ongoing positive changes can reap major improvements. For teaching, the 'continuous professional development' of the teachers is imperative to develop dynamism in the classroom and facilitate the teaching and learning process. This process can also be considered as a mingling of kaizen and professional development. The government along with the teacher-educators should take steps to enhance the professional development that emphasizes the complete assortment of "knowledge, skills, and attitudes required to educate learners effectively" [32]. Sparks and Richardson [31] think that a method of teaching may be only replaced by an innovative way to teach. Therefore, the study recommended that the teachers must be involved with learning activities for heightening their profession and teaching capabilities through proper utilization of the concept of kaizen and professional development. Moreover, ongoing professional development is essential if quality education to learners is desired [18].

\subsection{Habituating Resilience}

The study found that the teacher-participants were not satisfactorily interactive to the students. So, the present study recommended practicing resilience effectively so that the teachers can develop the connectivity with the students as much as one can accept the fact that change is an integral part of life, nurturing one's self positively and taking decisive actions as and when required. However, resilience is an aptitude to recuperate from or regulate candidly to bad luck or alteration. American Psychological Association [3] delineates that resilience is the progression of acclimatizing considerably to face the misfortune, catastrophe, or noteworthy causes of anxiety - such as personal and relational complications.

So, it is understandable that practicing and habituating resilience can bring the teachers the opportunity to get the utmost student responses as Espin and Yell [8] pointed out that effective teachers have higher rates of positive student retorts to their instructions. Resilience, thus, can enrich teachers' prosocial behavior credibly which is the besieged feature of this study. It means to be active back from problematic experiences.

\subsection{Effective Participation in Training and Teacher-research}

The study found $46.81 \%$ of teachers opining about the inefficacy of the trainings they received at different times. So, the present research recommended that all training programs must have an evaluation system because Oliver [20] mentioned that teacher preparation programs should "provide teacher candidates with instructional approaches 
for classroom management through coursework and guided practice with feedback" (p.4). Side by side, proper study materials and teaching aids with technological support should be provided by the authoritative body. Ho-Ming and Ping-Yan [13] accepted that a teacher's specialized training does not finish at the initial stage of pre-service training which is agreed by Somers and Sikorova [30] also. So, it is a continuous process of enriching one's capability of teaching and understanding of students' needs all of which cover the subject matter of prosocial behavior. The study also recommended a monitoring system whether the training outcomes are properly implemented or not after having the trainings as the govt. spends a handsome amount for arranging highly decorative training programs and workshops.

The study also urged that the secondary and higher secondary level teachers are hardly involved in research activities. If they worked on research papers, they would be able to develop their teaching tactics finding out their flaws and bringing the students' problems for solutions. MacLean and Mohr [19] opined that the teacher-researcher is an imperative fact to them because it redefines their roles as educators. In addition to that Khan [16] added that only research can give the teachers appropriate access to the newfangled dimension of knowledge and teaching tactics as the teacher-research can bring the broader pedagogies and comprehensive outcomes. So, the researcher believes that involvement in research works can increase the quality of education directly and indirectly.

\subsection{Proper Use of Non-verbal signals}

The interactions that teachers build up with the learners have a crucial function for the academic growth of the students. Frymier's [9] study found that the nonverbal dealings of the teachers like smiling with a soothing deportment, different facial and body languages come first in humanizing the didactic experiences for learners while the subject matter of the classroom itself comes later. As students' learning is a process of insight understanding and psychosocial facets, the teachers must develop a good connection with the learners in the class to give the best output through his smileys, soft attitude, good behavior, and positive implications. Furthermore, the teachers should be aware of the proper use of non-verbal cues to develop soft skills for better interaction with the students and to avoid any odd issue. Especially, when a student fails to perform as expected, a teacher must not show any mocking non-verbal signals that can affect psychologically because teachers must have a positive attitude to the students.

\section{Conclusions}

The study has elicited a real scenario of the current context for secondary and higher secondary education in
Bangladesh depicting the teachers' behaviors that affect students positively and negatively. Nevertheless, the study was not beyond limitations because the data was collected from the 16 institutions from only four districts through purposive sampling. There are six (6) other divisions in Bangladesh. So, the result may vary in other settings and contexts. Still, the paper suggests several implications that if the teachers' prosocial behaviors get improved and high standard, that would be very much supportive for the students to learn academic and humane behaviors. Besides, the textbooks or curriculum of the secondary level do not have any formal scopes or practical classes to learn such behaviors.

So, this impactful study emphasizes nurturing the teachers' prosocial behaviors with high standard compulsory training. Thus, the students can get the opportunities to become human resources for the country as well as the world. In other sense, such prosocial behaviors can make them more proficient and dynamic in future life of competition regarding higher education and career issues.

Yet again, the researcher chose the institutions from both urban and rural areas. Even three institutions were chosen from the suburban area to get varieties in the findings. However, the study finally concluded with an optimistic view that the government and the higher authority will take necessary steps to improve teachers' prosocial behaviors to make them more active in the broad-spectrum perspectives to create a smart and skilled generation. The study also left further scopes to study in the related issues like teachers' perceptions of post method pedagogy and utilizing neuro-linguistic programming at the secondary level ELT classrooms.

\section{Acknowledgement}

The study was partially supported by 'Hello-Teen Society' (govt. registration no. S-13170), an organization for education, research, and welfare in Bangladesh but was conducted by the author solely. The organization played no role in the conduct of the study but reviewed the project.

\section{REFERENCES}

[1] Alam, F. (2018). Revisioning English studies in Bangladesh in the age of globalisation and ELT. In Engaging in educational research, 241-261, Singapore: Springer, DOI: 10.1007/978-981-13-0708-9_13

[2] Allan, M. (1985). Teaching English with Video. Longman: Avon.

[3] American Psychological Association. (2019). The Road to Resilience. Retrieved 16 May 2019 from https://www.apa.o $\mathrm{rg} /$ helpcenter/road-resilience 
[4] Batson, C. D., Van Lange, P. A. M., Ahmad, N. \& Lishner, D. A. (2003). Altruism and helping behavior. In M. A. Hogg \& J. Cooper (Eds.), Sage handbook of social psychology, 279-295, London: Sage Publications.

[5] Blazar, D. \& Kraft, M. A. (2017). Teacher and Teaching Effects on Students' Attitudes and Behaviors. Educational Evaluation and Policy Analysis, 39(1), 146-170.

[6] Cohen, M. Z., Kahn, D. L., \& Steeves, D. L. (2000). Hermeneutic phenomenological research: A practical guide for nurse researchers. Thousand Oaks, CA: Sage.

[7] Cohen, D. K. (2011). Teaching and its predicaments. Cambridge, MA: Harvard University Press.

[8] Espin, C. A. \& Yell, M. L. (1994). Critical Indicators of Effective Teaching for preservice teachers: Relationships between teaching behaviors and ratings of effectiveness. Teacher Education and Special Education, 17, 154-169.

[9] Frymier, A. B. (1993). The impact of teacher immediacy on students' motivation: Is it the same for all students? Communication Quarterly, 41(4), 454-464.

[10] Gecer, A. (2013). Lecturer-student communication in blended learning environments. Educational Sciences: Theory and Practice, 13(1), 362-367.

[11] Gentles, S. J., Charles, C., Ploeg, J. \& McKibbon, K. A. (2015). Sampling in Qualitative Research: Insights from an Overview of the Methods Literature. The Qualitative Report, 20(11), 1772-1789.

[12] Hallinan, M. T. (2008). Teacher influences on students' attachment to school. Sociology of Education, 81(3), 271-283.

[13] HO-MING, N.G. \& PING-YAN, C. (1999). School-based teacher development in Guangzhou, China. International Studies in Educational Administration, 27(2), 32-42.

[14] Imai, M. (1986). Kaizen: The Key to Japan's Competitive Success. New York: McGraw-Hill Education.

[15] Joyce, B. (1980). Models of Teaching. Printice Hall Co., Englewood Cliffs. USA, 307-308.

[16] Khan, M. E. I. (2019). Justification of Using Post-method Pedagogy at Intermediate Level in Bangladesh: Teachers' Insights. Fareast International University Journal, 2(1): 105-114.

[17] Lampert, M. (2001). Teaching problems and the problems of teaching. New Haven, CT: Yale University Press.

[18] Louw, D. C. (1992). Differentiated staff development: A case study. Paper presented at The Second National Educational Management Congress, 10- 12 September.

[19] MacLean, M. S. \& Mohr, M. M. (1999). Teacher-researchers at work. Berkeley, CA: National Writing Project, p. vii-ix.

[20] Oliver, R. M. (2007). Effective Classroom Management: Teacher Preparation and Professional Development. National Comprehensive Center for Teacher Quality, Washington DC, Retrieved $20^{\text {th }}$ June from https://files.eric.ed.gov/fulltext/ED543769.pdf

[21] Pathak, A. \& Intratat, C. (2012). Use of Semi-Structured
Interviews to Investigate Teacher Perceptions of Student Collaboration. Malaysian Journal of ELT Research, 8(1), 01-10.

[22] Peters, J. H. (2012). Are they ready? Final Year Pre-service Teachers' Learning about Managing Student Behaviour. Australian Journal of Teacher Education, 37(9), 18-42.

[23] Pianta, R. C. \& Hamre, B. K. (2009). Conceptualization, measurement, and improvement of classroom processes: Standardized observation can leverage capacity. Educational Researcher, 38, 109-119.

[24] Qureshi, M. Z. (2013). The Good Teacher: A Qualitative Analysis of Perceptions of Asian American Parents. Doctoral Dissertation, Cornerstone: A Collection of Scholarly and Creative Works for Minnesota State University, Mankato, Retrieved from https://pdfs.semantics cholar.org/5fa7/7fd6ec0b34b2a6c1591b713374c40c869c7f. pdf

[25] Rahman, M. M., Islam, M.S., Karim, A., Chowdhury, T. A., Rahman, M. M., Seraj, P. M. I. \& Singh, M. K. M. (2019). English language teaching in Bangladesh today: Issues, outcomes and implications. Language Testing in Asia, 9(9) doi:10.1186/s40468-019-0085-8.

[26] Rahman, M. M., Johan, M., Selim, S. M. M., Singh, M. K. M., \& Shahed, F. H. (2019). Teachers' Beliefs and Practices of Implementing Secondary English Curriculum Reform in Bangladesh: A Phenomenological Study. Journal of Asia TEFL, 16(2), 591

[27] Rashid, M. A. \& SaeedUzZaman. (2018). Effects of Teacher's Behavior on Academic Performance of the Students. Conference Paper, 3rd International Conference on Research and Practices in education, Retrieved $12^{\text {th }}$ March, 2019 from https://www.researchgate.net/publication/32524 8514

[28] Shah, S. S. A. (2009). Impact of Teacher's Behaviour on the Academic Achievement of University Students. Journal of College Teaching and Learning, 6(1), 69-74.

[29] Shahmohammadi, N. (2014). Review on the Impacts of Teachers' Behavior on Students' Self-regulation. Procedia Social and Behavioral Sciences, 114, 130 - 135.

[30] Somers, J. \& Sikorova, E. (2002). The effectiveness of one in-service education of teachers course for influencing teachers' practice. Journal of In-Service Education, 28(01), 95-114.

[31] Sparks, D. \& Richardson, J. (1997). A primer on professional development. Journal of Staff Development, 18(4), 01-08.

[32] Steyn, G. M. \& van Niekerk, L. J. (2005). Professional Development of Teachers: Critical Success Factors. Koers, 70(01), 125-149.

[33] Südkamp, A., Kaiser, J. \& Möller, J. (2012). Accuracy of teachers' judgments of students' academic achievement: A meta-analysis: American Psychological Association.

[34] Ulug, M., Ozden, M. S. \& Eryilmaz, A. (2011). The effect of teachers' attitudes on student's personality and performance. Procedia-Social and Behavioral Sciences, 30, 738-742.

[35] Wallace, G. R. (1994). Discipline that motivates. Journal of Instructional Psychology, 21(4), 371-374. 